\title{
Creative thinking and foreign language education as the two main humanitarian components of contemporary higher education
}

\author{
Laurissa $V$. Milyaeva ${ }^{1^{*}}$ \\ ${ }^{1}$ Financial University under the Government of Russian Federation, Department of English Language \\ for Professional Communication, Moscow, Russia
}

\begin{abstract}
This article presents a brief theoretical overview of the issues of humanities education and its two components, namely, creative thinking and foreign language education. Within the framework of the present article, the author considers the definitions of the main terms, as well as foreign and domestic approaches to an aspect of contemporary education, such as humanitarian knowledge. The author also attempts to prove that, despite the pressure of information and communication technologies, the humanitarian aspect has not lost its importance in the training of modern specialists. Discussing the place of humanities education in the contemporary academic space, the author analyzes the current concepts of foreign and domestic scientists. Special attention in the theoretical review is paid to two main components of humanitarian knowledge, namely, creative thinking, and foreign language education. Creative thinking is presented as a special development component of the contemporary personality, who is formed through special creative tasks and is based on the processes of cognition and transformation of the acquired knowledge. Education received in a foreign language allows forming progressive competencies, such as socio-cultural competency and communicative competency in a foreign language.
\end{abstract}

Keywords: the humanities education, creative thinking, competencies, socio-cultural component.

\section{Introduction}

Quite possibly that many will find controversial and even strange the claim that contemporary education can't do without a humanitarian component, without having areas in higher education, which allow graduates to integrate the core curricula and elective courses, to combine the academic and experimential learning. Such education allows developing and improving specific skills and abilities that become then necessary for successful work, a full-fledged civic-minded attitude, and an active life [1-4].

Exactly this type of education will be discussed in the present article, where the main attention will be focused on aspects, such as creative thinking and its development in the

\footnotetext{
* Corresponding author: 1vmilyaeva@,fa.ru
} 
framework of professional education, as well as on a component, such as foreign language education $^{\dagger}$ and its implementation in the framework of contemporary education.

\section{Methods}

The main methods that were used to create a theoretical review and achieve the objectives set in this article included the methods of theoretical analysis of the relevant literature and interpretation of the data obtained. Thus, the authors conducted a general and comparative analysis of theoretical sources. The obtained data and provisions were compared and generalized. Based on the axiomatic method, abstract and general concepts and conclusions were brought to specific theses and concepts according to the tasks and goals of the article.

The corpus of theoretical sources included the works of contemporary domestic and foreign specialists and scientists who dealt with the issues of humanities education in general, as well as analyzed creative thinking and foreign language education, in particular. First of all, these were the works of E.I. Passov and A.N. Shchukin, the founders of the theory of foreign language education, who described the foundations and revealed the basic concepts of foreign language education; research and theoretical reviews of scientists A.V. Khutorsky, A. Harris, A. Loveless, P. Mishra dealing with the problems of creative thinking and the interaction of creative and technological approaches in the framework of contemporary education; as well as contemporary theoretical and practical works of domestic and foreign peers, T.V. Chernigovskaya, M.V. Melnichuk, M.A. Belogash, L.V. Milyaeva, and others, based on the experimental and professional experience of implementing the basics of the foreign language education in daily professional activities.

The results of the theoretical study are presented in the next section of the article.

\section{Results and discussion}

\subsection{Issues of the humanities education}

This section starts with a brief overview of the work of American researchers in humanities education. Members of the Association of American Colleges and Universities (AAC\&U), which is headed by Lynn Pasquerella, are engaged in theoretical issues of the humanities education, conduct field research, and address theoretical questions which are relevant to the contemporary world of technology, such as: What is the humanities education? For whom and why do one needs the humanities education? Where do they get the humanities education? In their publications, researchers note that currently humanities education is an inalienable part of the academic development and academic success of contemporary students, regardless of what they study, what their narrow specialization is, and what their career goals are [4].

Taking into account the research of the above-mentioned Association, as well as of the contemporary domestic scientists working in this area [1, 2, 5-7], the authors have reason to argue that contemporary society, having advanced information technologies and welltrained specialists-technocrats, is nevertheless not self-sufficient, since it needs the support and constant involvement of "... free-thinking people who are united in their commitment to the fundamental principles of the society in which they live, and in their intention to preserve, protect, and promote these principles; this refers to fairness, freedom, human dignity, and equality" [4].

\footnotetext{
$\dagger$ Here foreign language education is understood as the process of transmission and assimilation of both foreign language and foreign culture.
} 
Thus, the task of higher education with a tightly integrated humanitarian component is not just to help students acquire knowledge and skills but in the course of acquiring this knowledge to form habits and worldviews that will make future graduates advanced people, arm them with various skills of progressive existence, to encourage civic participation and the desire to create a society fair for all.

Russian scientists and teachers are also quite actively involved in the development of the theoretical and practical foundations of humanities education, arguing that exactly such education should form the basic moral values and guidelines. Thus, the humanities education acts as an indispensable characteristic of fundamental professional education and makes it possible "... to form not a narrowly trained professional but a person with a broad view of nature, the world, and human" [6].

As noted by I.M. Sheina, former rector of Ryazan State University named after S.A. Yesenin, the humanities education is integrated into the operating system of the entire university and "... is aimed at educating, forming a broad outlook, and the artistic taste of students. Young people are provided with ample opportunities for self-actualization - both personal and professional" [6].

What is the contradiction between the two main but radically different approaches to contemporary technocratic and humanitarian education? Analyzing the theoretical and applied works of contemporary researchers, in this article, the authors believe that they have every reason to state that the main difference is in the goals, objectives, and methods which characterize each approach. For example, the technocratic approach focuses on processes, such as standardization and unification of both industrial and production processes, as well as "...worldview attitudes, value ideas; in other words, this approach in the educational process focuses on the massification of consciousness" $[6,8]$. The humanitarian approach is used in a completely different area, based on the socio-cultural values and concepts, developing self-awareness, self-identification, and national identity, which in turn contributes to the creation and preservation of the uniqueness of educational and upbringing activities, as well as a comprehensive spiritual and moral formation of personality.

It seems very important and necessary to note the fact that the contemporary system of training specialists in higher professional education programs is characterized by the mandatory presence of a humanitarian component in the educational process, despite the active and, sometimes, aggressive information technology offensive in all sectors of human life. Advanced specialists, teachers, scientists, educators are well aware of the fact that without humanitarian knowledge, without the active development of critical and creative thinking, without foreign language education, it is impossible to fully develop and prosper a single nation or country, and the entire world community in general.

\subsection{Creative thinking in the context of the contemporary educational process}

Creative thinking at this development stage of the educational systems is one of the key concepts of the contemporary educational process being the research subject of many specialists involved in the field of contemporary education. The works of many leading Russian and foreign scientists show that the implementation of the creative approach in teaching in general and the development of creative thinking, in particular, are the main aspects of humanities education. $[3,5,9,10]$.

The paradigm within which contemporary secondary and specialized education develops often requires teachers and scientists, people of science and art to build the educational process so that it actively uses modern digital technologies, since the globalization processes and most importantly advanced technologies, digital gadgets, and 
applications create a new huge world of advanced pedagogical technologies and have very impressive impact on the formation of educational processes $[1,2,9]$.

Nevertheless, in the context of educational systems that are created based on contemporary educational institutions of higher education, the interaction of technologies and a creative approach to learning are clearly traced, which proves the fact that the presence of a creative component in the educational process is not just necessary but inevitable. Modern educational platforms and systems are expanding and constantly changing to meet the processes of general globalization and the rapid development of digital technologies, and exactly this fact speaks of the need to develop creative thinking and apply a creative approach to learning, and especially in those areas where the learning process is characterized by a high technological component $[10,11]$.

Certainly, one should not deny the fact that in contemporary education some researchers question the need to develop the creative component in students, to form the creative thinking skills in future specialists. Indeed, why is it needed to complicate the technically and mechanically structured educational process, if there are such technologies and software that will help today's specialists to cope with any task, whether it is a critical situation or the production of creative content? This may be the case but no program is capable of thinking creatively in the course of solving problem situations. The algorithms embedded in such programs, no matter how advanced they are, are nevertheless not able to look for unusual and nonstandard solutions to theoretical, practical, and applied problems $[12,13]$. This fact once again proves the authors' statement that “.... the ability to think outside the box in a new way must be developed in every student since this can help them to become competitive individuals and be actualized as successful contemporary specialists who will be able to find nonstandard ways to solve theoretical and practical problems not only within the framework of the university training program but also later in everyday professional or personal life" [2].

That is why most contemporary educational systems, educational platforms, and pedagogical technologies are built and developed taking into account the integration of digital technologies and a creative approach in educational processes, which meets all the needs and trends of modern society. At the present stage, the entire society is witnessing the formation of complex educational processes that take place in contemporary education and in the course of training specialists who can adapt to the endlessly changing conditions of modern life. Thus, higher professional education institutions face a very challenging task: to create "... new generations of specialists who are ready for constantly changing living conditions, who have not only fundamental knowledge but also creative initiative" $[2,3]$.

The level of efficiency of the formation and development of creative thinking in the academic environment depends on the set of creative tasks that the teacher offers students during the educational process. Such creative tasks are based on the processes of cognition, transformation, creation, and creative application of knowledge.

No matter how hard various advanced scientists try to instill the idea that humanities education is outdated and no longer in demand, the authors still dare to assert that modern education is an education with clearly expressed humanistic tendencies. A huge number of foreign and domestic higher education institutions actively and successfully implement a personality-oriented approach to learning, aimed at the direct development of students' personal characteristics and abilities, regardless of whether they receive education in the humanities, finance, or industry.

Concluding this section, it seems necessary to note that one of the leading components of Russian academic education has always been the humanitarian component, which is focused on a broad education and allows forming a fully developed personality with a highly developed socio-cultural competency in the course of the educational process. 


\subsection{Foreign language education and cross-cultural sensitivity}

This section of the present article deals with a brief consideration of the theoretical foundations of foreign language education as one of the components of humanities education. It seems necessary to start directly with the urgent question: why should such an aspect as foreign language education be included in the paradigm of humanitarian academic knowledge, and what is foreign language education in general?

The answer to these questions lies, oddly enough, on the surface and goes back to the concept of foreign language education. Since the concept of foreign language education is based on the study of a foreign language, it is not just a process of studying the morphology and grammar of the language of another peoplehood, but also the process of mastering the culture of this peoplehood, and, consequently, understanding the mentality of this peoplehood, its spiritual values, because all these aspects of human existence are embedded and reflected in the language $[5,9,11]$.

One of the main tasks of foreign language education is forming cross-cultural competency of students, which will later open up wide opportunities for young professionals, especially in the field of business or politics. Specialists, who have received a decent foreign language education, communicate more easily and fruitfully with business partners from a foreign language environment, understand the subtleties of international markets, international approaches to both education and production aspects, that is, have a high level of cross-cultural sensitivity [2].

The concept of cross-cultural sensitivity has already been considered in the authors' previous article where it was noted that this term "... should be understood as the awareness of differences and similarities between people and nationalities, without attributing any value to them, without describing them as negative or positive, as good or bad, right and wrong. In simple terms, this means that people understand that they are all different, and recognize the fact that no culture can be better than another." [2]

Thus, forming and developing cross-cultural communication and sensitivity occupy a key position in the framework of humanities education. The rapidity of life and development of today's world dictates certain conditions for the education systems development and improvement. In the modern humanitarian and business environment, various types of academic and business relationships are constantly being emerged and developed, which have long been not limited by physical or geographical boundaries. The active process of globalization of the academic world changes the educational process and goes beyond the borders of the territory where innovations were once engendered. All the aspects mentioned above explain the fact that foreign language education (knowledge of both foreign languages and foreign culture) occupies one of the leading positions when forming academic, professional, and business skills of students.

\section{Conclusion}

Taking into account all the above, the authors have reason to state that the successful formation and development of a comprehensive and auspicious personality in the modern academic environment take place within the framework of the humanitarian component. It is in such conditions that the creative thinking of students is actively formed, which is based on individual creative search and the flexibility of the academic mind. The combination of creative methods in the educational humanitarian process, as well as digital technologies and ICT contributes to the active development of the creative potential of students, and at the same time, forms progressive competencies, such as socio-cultural competency and communicative competency necessary for future specialists working in various fields. 


\section{References}

1. M.A. Belogash, M.V. Melnichuk, Rossiiskii Gumanitarnyi Zhurnal, 9(2), 123-132 (2020). https://doi.org/10.15643/libartrus-2020.2.4

2. L.V. Milyaeva, Samoupravleniye, 2(119), 352-355 (2020)

3. L.V. Milyaeva, Vyzovy sistemy obrazovaniya $\mathrm{v}$ epokhu tsifrovoy ekonomiki: matritsa vozmozhnostey [Challenges of the education system in the era of the digital economy: a matrix of opportunities]. (Nauchnyye tekhnologii, Moscow, 2020)

4. L. Pasquerrela and AAC\&U, What liberal education looks like (Association of American Colleges and Universities, Washington DC, 2020)

5. T.V. Chernigovskaya, Kak nauchit' mozg uchit'sya [How to Teach the Brain to Learn]. (Lektoriy pryamaya rech, Moscow, 2017)

6. I.M. Sheina, Gumanitarnoye obrazovaniye v sovremennom obshchestve [Humanities education in modern society] (n.d.). Accessed on: December 10, 2020. [Online]. Available: https://akvobr.ru/gumanitarnoe_obrazovanie_v_sovremennom_obshestve

7. D.B. Bogoyavlenskaya, Psikhologiya tvorcheskikh sposobnostey [Psychology of creativity] (Publishing Center Akademia, Moscow, 2002)

8. R.L. Spencer, Journal of Teacher Education, 26(3), 194 (1975). https://doi.org/10.1177/002248717502600301

9. E.I. Passov, Kommunikativnyy metod obucheniya inoyazychnomu govoreniyu [A communicative method of teaching foreign language speaking] (Prosveshcheniye, Moscow, 1985)

10. T.M. Amabile, Creativity in context (Westview Press Harper Collins Publishers, Boulder, 1996)

11. J. Hulstrand, International Educator, September-October, 24-31 (2008). Accessed on: December 10, 2020. [Online]. Available: https://www.nafsa.org/sites/default/files/ektron/files/underscore/ie_sepoct08_fluentwor $\mathrm{k}$

12. P. Mishra, the Deep-Play Research Group, Tech Trends, 56(5), 13-16 (2012). https://doi.org/10.1007/s11528-012-0594-0

13. P. Mishra, D. Henriksen, Creativity and technology: rethinking their role in education. (Springer, New York, 2018) 